http://dx.doi.org/10.12775/LinCop.2020.015

\author{
Anna NowakowsKa-GŁuszaK \\ Uniwersytet Śląski w Katowicach \\ Wydział Humanistyczny \\ ORCID: 0000-0002-8246-9480
}

\title{
Użycie wielkich liter w tekstach prawniczych w kontekście przekładu z języka hiszpańskiego na polski
}

\begin{abstract}
A b s t r a kt: Przedmiotem artykułu jest stosowanie wielkich liter w polskich i hiszpańskich tekstach prawniczych w kontekście przekładu. Wychodząc z założenia, że błędne użycie wielkich liter w tłumaczeniu wynika przede wszystkim z transferencji negatywnej, analizujemy czynniki mogące wpływać na pisownię nazw organów, instytucji i urzędów w tekstach prawniczych. Przeprowadzona analiza porównawcza wskazuje, że problem ma bardzo złożony charakter, gdyż wymaga uwzględnienia zarówno odmiennych zasad językowych, jak i norm o charakterze prawnym i instytucjonalnym (tłumaczeniowym), które w różnych konfiguracjach determinują zapis określonej nazwy. Dodatkowym czynnikiem utrudniającym właściwe tłumaczenie jest uzus kształtowany przez wspólnotę praktyków i wyraźna tendencja do majuskulizmu w hiszpańskim dyskursie prawniczym.
\end{abstract}

Słowa klucze: tłumaczenie prawnicze hiszpańsko-polskie; nazwy instytucji; wielkie litery; norma językowa; uzus językowy

Użycie wielkich liter w tekstach prawniczych w kontekście przekładu wydaje się problemem drugorzędnym. Przyjęło się uważać, że w tym zakresie zasady tłumaczenia są powszechnie znane i raczej uniwersalne. W konsekwencji trudno znaleźć szczegółowe opracowania czy wskazówki w literaturze specjalistycznej i podręcznikach dla przyszłych tłumaczy. Tymczasem, zdaniem 
A. D. Kubackiego, tłumacza przysięgłego i wieloletniego członka Państwowej Komisji Egzaminacyjnej na Tłumacza Przysięgłego przy Ministerstwie Sprawiedliwości, niewłaściwe użycie wielkich i małych liter, zarówno w języku obcym, jak i ojczystym, jest jednym z podstawowych błędów językowych popełnianych przez kandydatów na tłumacza przysięgłego (Kubacki 2012: 219).

W opinii Kubackiego większość błędów dotyczących wielkich i małych liter można tłumaczyć interferencją interlingwalną, zwaną także transferem negatywnym (por. Kozłowska 2002: 137), polegającą na przeniesieniu reguł ortograficznych z języka A na język B. W przypadku egzaminu mogą one również wynikać z „,nadmiernej generalizacji wcześniej przyswojonej reguły, nieznajomości odpowiedniej reguły oraz źródła natury psychiczno-fizjologicznej, jak np. stres, nerwowość czy pośpiech” (Kubacki 2012: 218). Naszym zdaniem problem jest o wiele bardziej złożony i wynika zarówno z odmiennych zasad ortograficznych języka wyjściowego i docelowego, czyli, w szerszym znaczeniu, normy językowej, jak i specyfiki dyskursu prawniczego wynikającej z natury samego prawa oraz uzusu kształtowanego przez dużą i niejednorodną grupę specjalistów.

W niniejszym artykule postaramy się omówić problem użycia wielkich liter w kontekście przekładu prawniczego z języka hiszpańskiego na polski, skupiając się na tłumaczeniu nazw urzędów, instytucji i stanowisk. Posłużą one jako przykład ukazujący złożoność omawianego tematu. Warto podkreślić, że w polskich badaniach nad tłumaczeniem specjalistycznym hiszpański jest nadal językiem nowym, wymagającym szerokiej i wieloaspektowej analizy praktycznie w każdym zakresie, sam temat zaś użycia wielkich liter w tekstach prawniczych, jak możemy wnioskować z lektury hiszpańskich źródeł (por. Gómez Font 2009; Montolío Durán 2012), budzi szereg wątpliwości i kontrowersji również na gruncie ojczystym.

\section{Ogólne zasady użycia wielkich liter w języku polskim i hiszpańskim}

Zasady użycia wielkich liter mają w każdym języku charakter konwencjonalny, co oznacza, że mogą ulegać pewnym zmianom na przestrzeni lat, ale jako takie zaliczane są do norm danego języka. Norma językowa to, jak czytamy w Encyklopedii językoznawstwa ogólnego (Polański 2003: 398), ,zbiór aprobowanych przez użytkowników języka jednostek językowych i ich po- 
łączeń". Normy, w przeciwieństwie do uzusu, czyli zwyczaju językowego, mają raczej stały charakter i nie dopuszczają dużej liczby wariantów, obejmując wyłącznie zjawiska ogólnie akceptowalne. Ich nieprzestrzeganie „grozi niezrozumieniem u odbiorcy albo zrozumieniem niezgodnym z intencjami nadawcy" (Polański 2003: 398). Możemy zatem założyć, że normy obowiązują wszystkich użytkowników języka.

Niewątpliwie zasady użycia wielkich i małych liter możemy zaliczyć do normy danego języka. Według Stownika ortograficznego PWN ${ }^{1}$ (2004: 40-58) opierają się one na czterech kryteriach: składniowym, graficznym, znaczeniowym oraz uczuciowo-grzecznościowym, przy czym to ostatnie ma mocno subiektywny charakter i zależy w znacznej mierze od intencji nadawcy i charakteru tekstu. W języku hiszpańskim obowiązują te same kryteria, choć redaktorzy Ortografii języka hiszpańskiego ${ }^{2}$ (2010: 442-519) nieco inaczej rozkładają akcenty, dzieląc zasady użycia wielkich liter ze względu na ich funkcję. Jako dwie podstawowe grupy wyróżniają: a) majuskuły służące delimitacji głównych jednostek tekstu; b) majuskuły wskazujące nazwy własne i wyrażenia denominatywne. I tak, do pierwszej grupy zaliczać będziemy wszelkie reguły wynikające z budowy wypowiedzenia lub tekstu, np. użycie wielkiej litery po kropce kończącej zdanie, ale również zasadę mówiącą, że po nagłówku pisma lub listu (np. Muy señor mío:, Estimados señores:, etc.) piszemy dwukropek, a ciąg dalszy w nowej linii zaczynamy wielką literą ${ }^{3}$ (Diccionario panhispánico de dudas ${ }^{4}$, reguła 3.3.). Istotna z punktu widzenia przekładu prawniczego jest również zasada pisowni wielkiej litery po dwukropku następującym po czasowniku wskazującym zasadniczą funkcję dokumentu o charakterze prawno-administracyjnym, np. w zaświadczeniu (hiszp. certificado): ... CERTIFICA: Que D. José Álvarez García ha seguido el Curso de Técnicas Audiovisuales... (OLE10: 454).

Druga grupa zasad jest zdecydowanie bardziej rozbudowana i należą do niej omawiane poniżej reguły pisowni nazw urzędów, instytucji i stanowisk.

${ }^{1}$ Dalej: SO PWN.

2 Ortografía de la lengua española (2010), dalej: OLE10.

${ }^{3}$ Gómez Font (2009: 188) jako jeden z podstawowych błędów popełnianych przez prawników wskazuje użycie przecinka zamiast dwukropka po nagłówkach i zwrotach do adresata na początku pisma czy listu. Według niego jest to kalka ortograficzna z angielskiego.

${ }^{4}$ Dalej: DPD. 


\section{Pisownia nazw urzędów i instytucji w języku polskim i hiszpańskim: zestawienie}

Zasady pisowni nazw urzędów i instytucji w obu językach wydają się dość proste i jasno określone. A zatem, zgodnie z regułami języka polskiego (SO PWN: 50), wielką literą należy pisać wszystkie człony indywidualnych nazw urzędów, władz, instytucji, szkół, organizacji, towarzystw (np. Trybunat Konstytucyjny, Uniwersytet Śląski, Stowarzyszenie Tłumaczy Polskich) z wyjątkiem przyimków, spójników, wyrażeń typu: imienia, pod wezwaniem, na rzecz, do spraw, numer, przeciwko. Wielką literą możemy również zapisać skróconą nazwę instytucji, jeśli została wymieniona wcześniej (np. Instytut Języka Polskiego zatrudnia 60 osób. W Instytucie prowadzone są badania...).

W języku hiszpańskim podobnie, wielką literą należy zapisać wszystkie znaczące elementy nazw urzędów, organów, instytucji, stowarzyszeń itd., również wtedy, gdy wyrażone są przez rzeczowniki pospolite (la Administración, el Gobierno, la Iglesia, el Ejército, la Hacienda Pública). Mówimy w tym przypadku o tzw. mayúscula diacrítica (diferencial), wynikającej z konieczności odróżnienia nazwy jednostkowej od użycia ogólnego (Martínez de Sousa 2010: 29)5. Gdy w odniesieniu do wyżej wymienionych jednostek używamy w tekście nazwy skróconej - najczęściej w funkcji anaforycznej - należy użyć małej litery, zwłaszcza gdy nazwa poprzedzona jest zaimkiem dzierżawczym (np. nuestro, vuestro), wskazującym (np. este) lub wyrażeniami typu dicho (pol. 'niniejszy'), citado (pol. 'cytowany', 'wskazany') (np. El programa fue diseñado por el Departamento de Lingüística Computacional. Este departamento se creó hace varios años.). Jeśli jednak pojawiają się z rodzajnikiem ( $e l, l a)$, możemy zapisać je wielką literą (por. El Departamento presentó los resultados de sus investigaciones) (OLE10: 484).

W języku hiszpańskim, podobnie jak w polskim, w nazwach instytucji należy zapisywać małą literą rodzajnik i spójnik, chyba że pełni on istotną funkcję semantyczną wewnątrz całej nazwy, tak jak np. Médicos Sin Fronteras (pol. 'Lekarze bez Granic'); Asociación Española Contra el Cáncer (pol. 'Hiszpańskie Stowarzyszenie przeciwko Rakowi’) (OLE10: 483). Polski, co widzimy, porównując obie wersje językowe, nie przewiduje takiej możliwości.

${ }^{5}$ Por. El ejército (= conjunto de tropas) no logró pasar la frontera. - pol. Wojsku (= oddziałom) nie udało się przekroczyć granicy. 


\section{Wpływ normy w obszarze prawa i normy instytucjonalnej na pisownię wielkich liter}

Jeśli ogólne zasady pisowni nazw urzędów i instytucji w obu językach, choć wykazują pewne różnice, wydają się przejrzyste, w momencie zastosowania na poziomie tekstu prawniczego, zwłaszcza w kontekście przekładu, tracą swą klarowność. Wynika to z faktu, że tekst prawniczy, podobnie jak tekst prawny ${ }^{6}$, funkcjonuje w specyficznym układzie komunikacyjnym zdeterminowanym nauką prawa, teorią i doktryną, które muszą zostać wzięte pod uwage przy jego analizie (Jopek-Bosiacka 2017: 27), oraz tym, że przekład tekstów prawnych (a w tym przypadku również prawniczych) ma charakter instytucjonalny, co wpływa m.in. na jego ocenę (Biel 2014: 70-72). Innymi słowy, na zastosowanie wielkich liter w tłumaczeniu nazw instytucji i stanowisk w tekstach prawniczych będzie mieć wpływ nie tylko norma językowa, ale również norma $\mathrm{w}$ obszarze prawa i norma tłumaczeniowa.

Normę w obszarze prawa rozumiemy za Jopek-Bosiacką jako „cechy systemu prawnego takie jak spójność i racjonalność oraz zasady prawne obowiązujące w danym systemie i kulturze prawnej, zasady techniki prawodawczej, a także dorobek nauki prawa, doktryny i orzecznictwa" (Jopek-Bosiacka 2017: 29), normę tłumaczeniową zaś ,jako normę instytucjonalną, wskazówki formalne, leksykalno-gramatyczne w danym obszarze komunikacyjnym i dla danego typu tekstu" (Jopek-Bosiacka 2017: 29). Za podstawowe źródła normy instytucjonalnej w tłumaczeniu prawniczym na język polski uznajemy Kodeks zawodowy tlumacza przysięgłego (2018) oraz Vademecum ttumacza. Wskazówki redakcyjne dla tlumaczy (2016) ${ }^{7}$ opracowane przez Departament Języka Polskiego Dyrekcji Generalnej ds. Tłumaczeń Pisemnych Komisji Europejskiej.

Uwzględnienie norm w obszarze prawa zakłada, między innymi, interpretację terminów używanych w tekstach normatywnych zgodnie z ich spe-

${ }^{6}$ Odwołując się do podziału na język prawny i prawniczy zaproponowanego w 1948 r. przez Wróblewskiego, przyjmujemy, że w zakresie omawianej problematyki „stosunek języka prawniczego do prawnego jest odtwarzający i przetwarzający” (Wróblewski 1948: 140).

${ }^{7}$ https://ec.europa.eu/translation/polish/guidelines/documents/styleguide_polish_dgt_ pl.pdf [dostęp: 22.10.2019]. 
cjalistycznym znaczeniem. Mamy tu na myśli przede wszystkim pojęcia, takie jak: urząd, organ, władze, instytucja. W analizowanych przez nas źródłach widać bowiem pewną prawidłowość: o ile w słowniku ortograficznym pojawiają się określenia: urząd, władze, instytucja (por. SO PWN), o tyle w zaleceniach Rady Języka Polskiego dla thumaczy w $\mathrm{UE}^{8}$ używany jest termin organ, podobnie w Vademecum tlumacza (2016), gdzie mowa o organach i instytucjach (por. podrozdział 1.2.1.5). Taki stan rzeczy może budzić, zwłaszcza u początkujących tłumaczy, uzasadnione wątpliwości. Przyjrzyjmy się zatem znaczeniu terminów: urząd i organ.

Według definicji w Słowniku języka polskiego PWN (online) organ to „urząd lub instytucja o określonej funkcji, zwłaszcza związanej ze sprawowaniem władzy”, natomiast urząd to „organ administracji państwowej o określonym zakresie działania; też: zespół osób i środków zapewniający realizację funkcji tego organu". Widzimy więc, że oba wyrazy mogą być traktowane w pewnych kontekstach jako synonimy, podstawowa różnica w definicji słownikowej wskazuje zaś na państwowy charakter organu. Tymczasem, zgodnie z art. 5 ust. 3 pkt 7 projektu ustawy przepisy ogólne prawa administracyjnego ${ }^{9}$, organ administracji publicznej to „wyodrębniona państwowa lub samorządowa jednostka organizacyjna albo inny podmiot, któremu na podstawie przepisów prawa powszechnie obowiązującego lub porozumienia administracyjnego powierzono wykonywanie, w formach władczych lub niewładczych, działań należących do administracji publicznej”. Do organów administracji publicznej należą np. ministrowie, organy administracji rządowej, wojewodowie, organy jednostek samorządu terytorialnego (np. wójt, burmistrz, starosta, organy gminy, organy województwa). A zatem organem może być jeden człowiek (organ jednoosobowy) lub grupa ludzi.

Powołanie organu wiąże się z utworzeniem i obsadzeniem urzędu, urząd zaś to ,zorganizowany zespół osób, środków rzeczowych i finansowych, przy pomocy których organ administracji publicznej wykonuje zadania" (art. 5 ust. 1 pkt 7 projektu przepisów ogólnych prawa administracyjnego).

8 Wielkie $i$ małe litery $w$ tekstach UE - ustalenia Zespołu Rady Języka Polskiego ds. Wspótpracy z Ttumaczami UE, poczynione na posiedzeniu Komisji Ortograficzno-Onomastycznej RJP 2 XII 2005 r. z uzupetnieniami z dnia 30.12.2005 r., http://www. rjp.pan.pl/index.php?option=com_content $\& v i e w=$ article $\& i d=1107$ :wielkie-i-mae-literyw-tekstach-ue\&catid=44\&Itemid=145 [dostęp: 10.10 .2019$]$.

9 Dostępne na https://www.rpo.gov.pl/pliki/12059280660.pdf [dostęp: 10.10.2019]. 
Urząd możemy rozumieć jako stanowisko zajmowane przez urzędnika administracji publicznej (np. (powołać na) urząd prezydenta, urząd dziekana, urząd sędziego, urząd burmistrza), jako instytucję (np. Urząd Stanu Cywilnego), jako przyznane kompetencje (sprawować urząd prezydenta), jako szczególną nazwę organu administracji publicznej (Urząd Celny) i w sensie strukturalno-administracyjnym (np. rektorat). Nietrudno się domyślić, że w każdym z tych przypadków obowiązywać będą odmienne zasady zapisu.

Wróćmy zatem do zasad pisowni urzędów, organów i stanowisk. Jak czytamy w SO PWN, zgodnie z ogólną zasadą, małą literą piszemy nazwy godności współczesnych i historycznych (np. prezydent RP, wojewoda śląski) oraz tytuły naukowe i zawodowe (np. profesor, doktor, inżynier). Zasadniczo małą literą piszemy również nazwy urzędów jednoosobowych, chyba że występują w aktach prawnych - wówczas należy je zapisać wielką literą (SO PWN, 51, reguła 85), np. Rzecznik Praw Obywatelskich stoi na straży wolności i praw czlowieka i obywatela określonych w Konstytucji oraz $w$ innych aktach normatywnych (art. 208 ust. 1 Konstytucji RP). Zgodnie ze zwyczajem pisownię wielkich liter można stosować również w tekstach o innym przeznaczeniu, jeśli nazwa taka odnosi się do konkretnej osoby i występuje w pełnym brzmieniu, niezależnie od tego, czy pojawia się przed imieniem i nazwiskiem, czy nie, np. Prezydent Rzeczpospolitej Polskiej odwiedzit nasze miasto; Zebranie otworzyt Naczelnik Gminy Lukasz Rudzki; Jan Kowalski zostat powołany na stanowisko Wojewody Małopolskiego (przykłady za SO PWN: 51).

Zasada ta stoi w pewnej sprzeczności z normą instytucjonalną wyrażoną w Vademecum thumacza (2016, podrozdział 1.2.1.5), gdzie wskazuje się, że należy odróżnić użycie odnoszące się do organu od wskazania osoby lub funkcji (sprawowanego urzędu): „nazwy funkcji, stanowisk piszemy również od małych liter (...). Pisownia zależna jest jednak od kontekstu - jeżeli określenie Komisarz UE do spraw Konkurencji występuje w tekście w znaczeniu nazwy organu, właściwy jest zapis wielkimi literami, ale gdy określenie komisarz UE ds. konkurencji pojawia się w znaczeniu osoby lub funkcji, często w połączeniu z nazwiskiem, należy je zapisać małymi literami” (Vademecum thumacza, 2016, podrozdział 1.2.1.14).

Przypomnijmy jednocześnie, że zgodnie z zasadami zawartymi w Vademecum... (podrozdział 1.2.1.5), wszystkie znaczące człony oficjalnych nazw 
własnych instytucji i organów należy pisać wielkimi literami, co oznacza, że norma instytucjonalna pokrywa się w tym zakresie $\mathrm{z}$ normą językową.

Według zasad języka hiszpańskiego, nazwy urzędów i stanowisk, niezależnie od ich rangi i charakteru, powinny być zapisywane małą literą, choć zwyczajowo w ustawach, dekretach i dokumentach urzędowych przyjęło się stosowanie wielkich liter w przypadku najwyższych stanowisk, np. el Rey de España, el Jefe de Estado, el Presidente del Gobierno (DPD, reguła 4.31). Poza tym dopuszczalne (choć nieobowiązkowe) jest użycie wielkiej litery przy nazwie godności lub stanowiska w odniesieniu do konkretnej osoby, gdy nie podajemy jej imienia i/lub nazwiska. Wielka litera może zostać również zastosowana w nagłówku listu. W pozostałych przypadkach powinna zostać użyta mała litera. Martínez de Sousa (2010: 42) podaje jako właściwe następujące wersje: el ministro de Hacienda, la ministra de Cultura, rector czy presidente ${ }^{10}$ (w znaczeniu 'prezydent').

By praktycznie zilustrować problem, weźmy krótki fragment publikacji opisującej funkcjonowanie instytucji unijnych w kontekście prawa polskiego: El Tribunal de Justicia (Trybunat Sprawiedliwości) está compuesto por 27 Jueces y 8 Abogados Generales, designados de común acuerdo por los Gobiernos de los Estados miembros por un período de seis años (...). El actual Juez de Polonia es Jerzy Makarczyk (desde 11 de mayo de 2004). Los Jueces del Tribunal de Justicia eligen de entre ellos al Presidente del Tribunal de Justicia... (Supera-Markowska 2009: 136). Przede wszystkim zwróćmy uwagę na pisownię po hiszpańsku. W tekście pojawia się nazwa instytucji (Tribunal de Justicia) pisana, zgodnie z zasadami, w całości wielką literą. Pozostałe użycia (jueces, juez, abogados generales, gobiernos, presidente) budzą jednak pewne wątpliwości, gdyż w kontekście przytoczonych wcześniej zasad oczekiwać można zapisu małą literą. Ciekawym przypadkiem jest określenie Estados miembros (państwa członkowskie): jak podaje DPD, Estado (państwo), pomimo że jest rzeczownikiem pospolitym, pisze się wielka litera, gdy oznacza całość organów kierujących suwerennym państwem lub odnosi się do kraju stanowiacego jednostke polityczna lub jego terytorium ${ }^{11}$. $\mathrm{W}$ tłumaczeniu na język polski cytowany fragment powinien mieć następu-

10 Presidente może w języku hiszpańskim znaczyć również 'prezes', 'przewodniczący'.

11 https:/www.fundeu.es/recomendacion/estados-miembros-grafia-apropiada-75/ [dostęp: 10.10.2019]. 
jący zapis: „Trybunał Sprawiedliwości składa się z 27 sędziów i 8 rzeczników generalnych, wybieranych za wspólnym porozumieniem rządów państw członkowskich na okres sześciu lat (...). Obecnie polskim sędzią jest Jerzy Makarczyk (od 11 maja 2004 r.). Sędziowie Trybunału Sprawiedliwości wybierają spośród siebie prezesa Trybunału Sprawiedliwości...” Użycie wielkich liter pokrywa się tu z zapisem w Traktacie o funkcjonowaniu Unii Europejskiej (np. art. 253). Wyjątek stanowią ,państwa członkowskie”, które w powyższym akcie prawnym są traktowane jako strony umowy i, tym samym, zapisane wielką literą ${ }^{12}$. Ponieważ jednak tłumaczony przez nas tekst ma charakter prawniczy naukowy (por. Zieliński 1999: 64-72), zastosowaliśmy inną pisownię.

\section{Wpływ uzusu językowego na stosowanie wielkich liter}

Do tej pory analizowaliśmy różnice między polską i hiszpańską normą językową oraz wpływ normy instytucjonalnej na strategie tłumaczenia elementów tekstu prawniczego. Pamiętając jednak, że przedmiotem i efektem tłumaczenia jest konkretny tekst, skierowany do określonego odbiorcy-specjalisty (najczęściej prawnika), musimy uwzględnić przyjętą praktykę komunikacyjną, czyli tzw. uzus. Ciekawą ilustracją tego problemu jest zwyczaj zapisywania wielką literą nazw urzędów i zawodów sądowych w hiszpańskich tekstach prawniczych, widoczny również $\mathrm{w}$ analizowanym przykładzie. Zanim jednak szczegółowo omówimy tę kwestię, postaramy się uściślić samo pojęcie uzusu oraz jego znaczenie w komunikacji prawniczej.

Uzus $^{13}$ językowy to „przyjęty w danej społeczności sposób posługiwania się systemem językowym, jego jednostkami i regułami ich łączenia” (Polański 2003: 623). Kształtowany jest przez tzw. 'wspólnotę praktyków' (community of practice), czyli zbiór osób, które piszą (i mówią) zgodnie z określonymi zwyczajami, czerpiąc z istniejących już tekstów (Wenger 1998): „Każdy specjalista przez większość czasu pracy ma kontakt z tekstami z zakresu

12 „Wyrażenie państwa członkowskie pisze się małymi literami. W cytatach należy również stosować małe litery. Warto jednak pamiętać, że państwa członkowskie w umowach i traktatach, których są stroną, zapisuje się wielkimi literami (Państwa Członkowskie) celowo, zgodnie z zasadą dotyczącą pisowni nazw stron umowy" (Vademecum ttumacza, podrozdział 1.2.1.14).

13 Uzus, z łac. usus - użycie, używanie. 
swojej dziedziny, posiadającymi określone cechy i właściwości, wydaje się zatem logiczne, że gdy sam musi stworzyć tekst, powiela te cechy" (Montolío Durán 2012: 68).

W przypadku języka prawniczego mamy do czynienia $z$ dużą i mocno zróżnicowaną wewnętrznie wspólnotą. Dodatkowo musimy pamiętać, że na poziomie komunikacyjnym wchodzi ona $\mathrm{w}$ interakcje $\mathrm{z}$ przedstawicielami innych zawodów - biegłymi z różnych dziedzin, funkcjonariuszami policji, urzędnikami itd. Wzajemna korelacja między nimi sprzyja utrwalaniu się i uniwersalizacji, również poza środowiskiem, cech formalnych i stylistycznych języka prawników. W konsekwencji w powszechnym przekonaniu zaczynają być one uznawane za „normalne”, a tym samym poprawne, w tekstach prawniczych (Montolío Durán 2012: 68). Tymczasem, co zaznaczają badacze tematu, niejednokrotnie mamy do czynienia z błędnym użyciem języka. Dowodzą tego jednoznacznie wnioski płynące z raportu na temat języka tekstów prawniczych, głównie wyroków sądowych, opublikowanego przez Komisję ds. Modernizacji Języka Prawnego (Comisión para la Modernización del Lenguaje Jurídico) działającą przy hiszpańskim Ministerstwie Sprawiedliwości, pt. Estudio de campo: lenguaje escrito (2015).

Według Montolío Durán, koordynatorki zespołu badawczego, jednym z podstawowych błędów w hiszpańskich tekstach prawniczych jest nieuzasadnione użycie wielkich liter. Autorka mówi nawet o swego rodzaju „majuskulizmie" (mayusculismo) polegającym na patologicznej tendencji do nadmiernego, nieuzasadnionego i niejednorodnego użycia wielkich liter wbrew normom języka hiszpańskiego (Montolío Durán 2012: 78). Według autorów Estudio... (2015: 167) wynika ona z nieznajomości zasad języka hiszpańskiego (norma del estándar pahispánico) oraz chęci podkreślenia znaczenia niektórych tytułów czy stanowisk bądź segmentów tekstu.

Pisownia wielką literą nazw odnoszących się do zawodów prawniczych (np. Abogado, Procurador czy Juez) czy stanowisk związanych z administracją (np. Director General, Secretario, Presidente) jest wg Gómeza Fonta (2009: 192) jednym z najczęstszych i najtrudniejszych do wykorzenienia błędów w tekstach prawniczych. Wynika głównie z kryteriów, które zakwalifikowalibyśmy jako grzecznościowe i służy podkreśleniu wagi określanego stanowiska. Dodatkowo, co potwierdziła nasza analiza wyroków umieszczonych w hiszpańskiej bazie dokumentacji sądowej CENDOJ (http://www.poderjudicial.es/search/indexAN.jsp), niejednokrotnie obok na- 
zwy juez (pol. 'sędzia'), abogado (pol. 'adwokat') czy fiscal (pol. 'prokurator') pojawiają się w formie pełnej lub skróconej zwroty grzecznościowe typu Sr. (Señor), D. (Don), Ilmo. Sr. (Ilustrísimo Señor), Excmo. Sr. D. (Excelentísimo Señor Don), np.:

Iltmo. Sr. Presidente: Don José Arsuaga Cortázar (SAP S 280/2019),

Iltmos. Sres. Magistrados: Don Bruno Arias Berrioategortua. Doña Milagros Martínez Rionda (SAP S 280/2019),

Letrada de la Administración de Justicia: Ilma. Sra. Dña. María Jesús Pera Bajo (STS 3192/2019),

które z semantycznego punktu widzenia są redundantne i nieprzekładalne w tym kontekście na język polski.

Według autorów raportu Estudio de campo: lenguaje escrito (2015) użycie powyższych zwrotów grzecznościowych, podobnie jak wielkiej litery, w odniesieniu do przedstawicieli zawodów prawniczych w tekstach wyroków jest nieuzasadnione i może wpływać negatywnie na czytelność dokumentu. Ponadto językoznawcy słusznie zauważają, że widoczna asymetria na poziomie tekstu, polegająca na (nad)używaniu wyrażeń grzecznościowych w odniesieniu do sędziów, prokuratorów i innych przedstawicieli władzy sądowniczej przy jednoczesnym traktowaniu stron biorących udział w postępowaniu (np. powód/-ka, pozwany/a, oskarżony/a itd.) w sposób bezpośredni, wyraża hierarchiczną relację między państwem i obywatelem, nieodpowiadającą zasadom współczesnego państwa prawa: „Uważamy, podobnie jak Tomás Ríos (2005), że tytuły i zwroty grzecznościowe narzucają w treści wyroków ton autorytarno-podporządkowujący, który pogłębia dystans między osobami sprawującymi władzę sądowniczą o przeciętnym obywatelem” (Estudio... 2015: 140).

Widzimy zatem wyraźnie, że w tekstach prawniczych obok norm o charakterze językowym i prawnym funkcjonuje pewien uzus, który chyba w największym stopniu determinuje praktykę użycia wielkich liter. Wynika to, $\mathrm{z}$ jednej strony, z natury funkcjonowania społeczności praktyków, która sprzyja powielaniu pewnych zjawisk językowych, z drugiej zaś - z nieznajomości zasad ortograficznych języka bądź ich zawiłości. Pojawia się zatem pytanie, jak traktować uzus i czy może on zastąpić normę. Przede wszystkim 
musimy przypomnieć, że choć uzus może, w dłuższej perspektywie, zmodyfikować normę językową, „nie wystarcza powszechność w jednym środowisku, w jednej odmianie języka" (Polański 1999: 623). Poza tym uzus jest zawsze oceniany w relacji zgodności z normą; jeśli jest od niej inny, stanowi odstępstwo, naruszenie normy. „Uzus może mieć znaczenie przy braku normy, ale nie może być niezgodny z normą" (Jopek-Bosiacka 2017: 38). Tym samym musimy uznać, że użycia, które analizowaliśmy powyżej, należy traktować jako błędy językowe, które nie powinny mieć wpływu na kształt tłumaczenia.

\section{Wnioski}

Punktem wyjścia naszego artykułu była teza, że błędy w użyciu wielkich liter $\mathrm{w}$ tłumaczeniu prawniczym wynikają przede wszystkim z negatywnej transferencji zasad ortograficznych między językiem oryginału i językiem przekładu. Przeprowadzona analiza reguł pisowni nazw urzędów, instytucji i stanowisk częściowo ją potwierdza. Jak wykazaliśmy, między normą ortograficzną języka polskiego i hiszpańskiego istnieją pewne różnice, które, nieuświadomione, mogą powodować błędy w tłumaczeniu. Sam problem pisowni wielkich liter w tekstach prawniczych jest jednak o wiele bardziej złożony, gdyż wymaga od tłumacza uwzględnienia czynników o charakterze pozajęzykowym, wynikających z samej natury prawa (norma w obszarze prawa), specyfiki przekładu (norma tłumaczeniowa) oraz uzusu kształtowanego przez wspólnotę praktyków.

Podsumowując naszą analizę, możemy sformułować następujące wnioski: błędne użycie wielkich liter w tłumaczeniu nazw instytucji w tekstach prawniczych $\mathrm{z}$ hiszpańskiego na polski wynika z czterech podstawowych przyczyn. Są to:

a) odmienne zasady użycia wielkich liter w języku wyjściowym i docelowym;

b) odmienne od zasad ogólnych reguły użycia wielkich liter w tekstach prawnych i prawniczych w jednym lub obu językach (np. pisownia nazw organów jednoosobowych);

c) uzus (zwyczaj) kształtowany przez wspólnotę praktyków, w tym powielane błędy językowe, które mogą zostać błędnie zinterpretowane jako semantycznie istotne; 
d) niespójność zapisów pojawiających w różnych źródłach o charakterze normatywnym (ustawy, akty prawne) i opracowaniach (słowniki, podręczniki, artykuły naukowe itp. $)^{14}$.

Choć przedmiotem przedstawionej analizy jest tłumaczenie hiszpańsko-polskie, możemy założyć, że wnioski, do których prowadzi, mają zastosowanie uniwersalne i wpisują się w ogólną refleksję na temat przekładu prawniczego, w szczególności na problem relacji między normą (normami) a uzusem. Ten ostatni, jak wiadomo, może współistnieć z normą (lub normami), zastępować ją lub pozostawać w sprzeczności (por. Polański 1999: 623). Z tego też powodu tłumacz w każdym indywidualnym przypadku musi odpowiedzieć sobie na pytanie, z którym typem relacji ma do czynienia. W tłumaczeniu prawniczym najważniejsza jest bowiem norma, uzus może być brany pod uwagę w przypadku jej braku (Jopek-Bosiacka 2017: 38). Jeśli uzus jest sprzeczny z normą, może zostać potraktowany jako błąd. By jednak tłumacz mógł dojść do takiego wniosku, musi mieć świadomość reguł i zasad obowiązujących w obu językach i systemach prawnych.

\section{Bibliografia}

BIEL Ł., 2014, Lost in the Eurofog: The textual fit of translated texts, Frankfurt am Main: Peter Lang.

CENDOJ. Centro de Documentación Judicial, [online] http://www.poderjudicial.es/ search/indexAN.jsp. [dostęp: 23.10.2019].

Comisión para la Modernización del Lenguaje Jurídico, 2015, Estudio de campo: lenguaje escrito [online] https://lenguajeadministrativo.com/wp-content/uploads/2015/10/CMLJ-Lenguaje-escrito.pdf [dostęp: 23.10.2019].

Departament Języka Polskiego. Dyrekcja Generalna ds. Tłumaczeń Pisemnych. Komisja Europejska, 2016, Vademecum ttumacza. Wskazówki redakcyjne dla tlumaczy, [online] https://ec.europa.eu/translation/polish/guidelines/documents/styleguide_polish_dgt_pl.pdf [dostęp: 20.10.2019].

Diccionario panhispánico de dudas, [online] https://www.rae.es/recursos/diccionarios/dpd [dostęp: 23.10.2019].

14 Analiza źródeł pod kątem zasad użycia wielkich liter w tekstach prawniczych pozwala nam stwierdzić, że nawet w wiarygodnych źródłach (np. teksty ustaw, podręczniki z zakresu języka specjalistycznego, artykuły pisane przez hiszpańskich autorów itp.) pojawiają się różnorodne zapisy, niezgodne z hiszpańską normą ortograficzną. 
Fundéu BBVA, [online] https://www.fundeu.es [dostęp: 10.10.2019].

Gómez Font A., 2009, Abogacía y corrección idiomática, Revista de Llengua i Dret 51, s. 187-200.

Jopek-Bosiacka A., 2017, Między normą a uzusem. O roli teorii prawa i doktryny w procesie oceny jakości przekładu prawnego, w: B. Walkiewicz, K. Kęsicka (red.), Norma a uzus II. Przektad specjalistyczny w perspektywie globalizacji, Poznań: Wydawnictwo UAM, s. 27-40.

Kodeks zawodowy tlumacza przysięgłego, 2018, [online] https://tepis.org.pl/wp-content/uploads/Kodeks-zawodowy-t\%C5\%82umacza-przysi\%C4\%99g\%C5\%82ego-2018.pdf [dostęp: 20.10.2019].

Kozıowska Z., 2002, O błędach językowych w tekstach polskich przekładów, w: A. Kopczyńska, Z. Zaliwska-Okrutna (red.), Język rodzimy a język obcy, komunikacja, przektad, dydaktyka, Warszawa: Wydawnictwo UW, s. 137-147.

Kubacki D. A., 2012, Ttumaczenie poświadczone. Status, kształcenie, warsztat i odpowiedzialność ttumacza przysięglego, Warszawa: Lex a Wolters Kluwer.

Martínez de Sousa J., 2010, Diccionario de uso de las mayúsculas y minúsculas, Gijón: Ediciones Trea, S.L.

Montolío Durán E. (red.), 2012, Hacia la modernización del discurso jurídico, Barcelona: Universidad de Barcelona.

PolańsKi K. (red.), 1999, Encyklopedia językoznawstwa ogólnego, Wrocław: Ossolineum.

Projekt ustawy Przepisy ogólne prawa administracyjnego, [online] https://www.rpo. gov.pl/pliki/12059280660.pdf [dostęp: 20.10.2019].

Real Academia Española, 2010, Ortografía de la lengua española, Madrid: Espasa Libros.

Stownik języka polskiego PWN, [online] http://sjp.pwn.pl [dostęp: 22.10.2019].

Stownik ortograficzny PWN, 2004, Warszawa: Wydawnictwo Naukowe PWN.

SuPera-MarkowsKa M., 2009, Zarys prawa hiszpańskiego i prawa polskiego. Esbozo del derecho español y del derecho polaco, Warszawa: C.H. Beck.

Tomás Ríos J., 2005, Las sentencias judiciales, estudio y análisis sociolingüístico, Tonos. Revista Electrónica de Estudios Filológicos 9, [online] https://www. um.es/tonosdigital/znum9/corpora/juridicos.html [dostęp: 23.10.2019].

Traktat o funkcjonowaniu Unii Europejskiej, [online:] https://eur-lex.europa.eu/legal-content/PL/TXT/?uri=celex\%3A12012E\%2FTXT [dostęp: 10.10.2019].

Wenger E., 1998, Communities of Practice: Learning, Meaning and Identity, New York: Cambridge University Press.

Wielkie i małe litery w tekstach UE - ustalenia Zespołu Rady Języka Polskiego ds. Wspótpracy z Ttumaczami UE, poczynione na posiedzeniu Komisji Ortograficzno-Onomastycznej RJP 2 XII 2005 r. z uzupetnieniami z dnia 30.12.2005 r., 
[online] http://www.rjp.pan.pl/index.php?option=com_content\&view=article\&id= 1107:wielkie-i-mae-litery-w-tekstach-ue\&catid=44\&Itemid=145 [dostęp: 10.10.2019].

Wróblewski B., 1948, Język prawny i prawniczy, Kraków: Nakł. Polskiej Akademii Umiejętności.

ZieliŃski M., 1999, Języki prawne i prawnicze, w: W. Pisarek (red.), Polszczyzna 2000. Orędzie o stanie języka na przełomie tysiącleci, Kraków: Ośrodek Badań Prasoznawczych, Uniwersytet Jagielloński, s. 50-74.

\section{The capitalization in legal texts in the context of translation from Spanish into Polish \\ ( s u m mary)}

The aim of the article is to analyze the use of capital letters in Polish and Spanish legal texts from the translation perspective. Referring to the hypothesis that the problems of orthographic nature arise mainly due to the negative interference, we consider other factors that may influence the problem. The comparative analysis proves that translators of the legal texts (e.g. sworn translators) have to take into consideration not only linguistic but also institutional and legal factors, as well the usage created by the community of practice.

Ke y w ords: legal translation Spanish-Polish; names of institutions; capital letters; linguistic norm; linguistic usagew 
